\title{
Transitivity in Pazar Laz*
}

\author{
Eser Erguvanlı Taylan \\ Boğaziçi University \\ taylanes@boun.edu.tr \\ Balkız Öztürk \\ Boğaziçi University \\ balkiz.ozturk@boun.edu.tr
}

\begin{abstract}
This study argues that in Pazar Laz, all verb types have a transitive syntax involving both an initiator and an undergoer. Thus, there are no truly intransitive verbs, such as unaccusatives and unergatives. All eventualities are argued to involve a relationship between an initiator and an undergoer and are strictly mapped onto syntax transitively in Pazar Laz.
\end{abstract}

Keywords: transitivity; unergatives; unaccusatives; statives; lexical aspect

\section{Introduction}

This study argues that all eventualities in Pazar Laz (PL) are constructed transitively in syntax involving a relationship between an initiator and an undergoer. ${ }^{1}$ That is, not only transitives, but also unergatives, unaccusatives and statives have a transitive composition. While unergatives and unaccusatives involve syntactically active implicit undergoers and initiators, respectively, statives are derived from eventive transitive verbs.

As well observed in the literature (Hopper \& Thompson 1980; Levin 1999, among others), semantic transitivity requires two participants in the event structure, one of which has agency features, such as volition,

* We thank our informant İsmail Avcı Bucak'liși for providing us with the Pazar Laz data and the Boğaziçi University Research Fund (Project no: 12BO4P2-6680) for supporting Balkız Öztürk's research. We also thank the two anonymous reviewers for their invaluable comments and suggestions. Naturally we take the responsibility for any shortcomings in the paper.

${ }^{1}$ Laz is an endangered Caucasian language spoken in Turkey, which forms the southern branch of Caucasian languages along with Migrelian, Svan and Georgian. Laz is mainly spoken in Turkey and has five major dialects: Pazar (Atinan), Ardeshen, Arhavi, Findıklı, and Hopa. See Anderson (1963); Kutscher et al. (1995); Lacroix (2009) and Öztürk \& Pöchtrager (2011) for a description of Findıklı, Ardeshen, Arhavi and Pazar dialects, respectively.

1216-8076/\$20.00 (C) 2014 Akadémiai Kiadó, Budapest 
kinesis, action, while the other is the participant affected by the act of the first participant. There is not necessarily an overlap between syntactic and semantic transitivity as seen in (1):

(1) a. The engineer destroyed the bridge. (patient)

b. The engineer reached the bridge. (goal) (Levin 1999, 2)

While the syntactic object the bridge in (1a) is also the semantic object, which is fully affected by the act of the agent subject the engineer, in (1b) semantically the same syntactic object denotes a goal, rather than an affected participant in the event structure. In PL, however, we will show that there is one to one mapping between semantic and syntactic transitivity. Furthermore, we will argue that all eventualities in PL have an initiator acting upon an undergoer. Thus, eventualities, such as activities, accomplishments, achievements, as well as statives share the same representation in syntax, where an initiator and an undergoer are present. Yet, although all eventualities share the same syntax, they can be presented either through the perspective of the causer/initiator or through that of the undergoer. This is achieved via the use of thematic suffixes, a morphological tool which reflects argument structure, as well as eventuality type.

Through the use of thematic suffixes it is possible to construct intransitive patterns such as unergatives and unaccusatives in PL, where the verb appears with a single DP argument on the surface. We will show that even in these constructions there is an implicit initiator for unaccusatives and an implicit undergoer for unergatives, which are syntactically active and may be morphologically marked dependent on the verb type.

In the following section we introduce the different thematic suffixes in the language and discuss what kinds of semantic and syntactic information each one encodes. In section 3 we present evidence for the transitive structure of all types of eventualities and conclude with a schematic representation of PL verb types (section 4).

\section{Thematic suffixes and PL verb classes}

The classification of verbs in PL is coded on the verb through thematic suffixes (TS). The particular thematic suffix a verb selects denotes its semantic and syntactic properties related to event and argument structure. There are four different TSs in PL: Underived verbs can select either -um, $-a m$, or $-u(r)$, depending on the semantics of the verb as in $(2 \mathrm{a}),(2 \mathrm{~d})$, 
(3a-b) and (4), respectively. The fourth marker $-e(r)$, on the other hand, is always used in combination with the valency marker $i$ - and constructs unaccusative intransitive verbs derived from transitives selecting -am or -um as in (5). The TS renders the eventuality temporally present and aspectually imperfective, encompassing both the progressive and the habitual, as seen in (2a), (2d), (3)-(5) below. In the past it simply expresses imperfectivity as illustrated by the contrast between $(2 \mathrm{~b})$ and $(2 \mathrm{c}){ }^{2}$

(2) a. Ahmedi-k dişk'a p'-t'ax-um-s.

(present)

Ahmedi-ERG wood 1SBJ-break-TS-PRS.3SG

'Ahmet is breaking/breaks wood.'

b. Ahmedi-k dişk'a p'-t'ax-u.

Ahmedi-ERG wood 1SBJ-break-PST.3SG

'Ahmet broke wood.'

c. Ahmedi-k ğoma dişk'a p'-t'ax-um-t'u. (past +imperfective)

Ahmedi-ERG yesterday wood 1SBJ-break-TS-COP.PST.3SG

'Ahmet was breaking the wood yesterday.'

d. Ahmedi-k oxori tzopsx-um-s.

Ahmet-ERG house build-TS-PRS.3SG

'Ahmet is building the house/Ahmet builds houses.'

(3) a. Ahmedi-k toyiç'i zd-am-s.

Ahmet-ERG rope pull-TS-PRS.3sG

'Ahmet is pulling/pulls the rope.'

(4) a. Mjora c-ul-u-n.

sun PV-move-TS-PRS.3SG

'The sun is setting/sets.' b. Ahmedi-k dişk'a me-ğ-am-s.

Ahmet-ERG wood PV-bring-TS-PRS.3SG 'Ahmet is bringing/brings wood.'

b. Balon-epe t'vats-u-n balloon-PL pop-TS-PRS.3SG

'The balloons are popping/pop.'

(5) Dişk'a i-t'ax-e-n.

wood VAL-break-TS-PRS.3SG

'Wood is (being) broken.'

${ }^{2}$ Examples in Pazar Laz are given as they are written in the language. The PL writing system is based on Turkish orthography. The letters in PL orthography whose phonetic values need specification are: $c=/ \mathrm{d} / ; c=/ \mathrm{t} / ; \breve{g}=/ \mathrm{y} / ; x=/ \mathrm{x} /$; $\S=/ \mathrm{J} /$. Note that PL has ejectives represented with an apostrophe, e.g., $k$ '. The abbreviations used are the following: $\mathrm{ALLAT}=$ allative; $\mathrm{APPL}=$ applicative; $\mathrm{CAUS}=$ causative; $\mathrm{COP}=$ copula $; \mathrm{DAT}=$ dative $\quad \mathrm{ERG}=$ ergative; $\mathrm{IMP}=$ imperfect $; \mathrm{POSS}=$ possessive; $\mathrm{PRS}=$ present; $\mathrm{PV}=$ preverbal marker; $\mathrm{REFL}=$ reflexive; $\mathrm{SG}=$ singular; $\mathrm{SBJ}=$ subject; $\mathrm{TS}=$ thematic suffix; $\mathrm{VAL}=$ valency marker . 
The verbs in (2a), (2d) and (3), though they select different TSs, are transitives involving both an overt nominative object and an overt ergative subject, while (4) and (5) are intransitive on the surface and only have an overt nominative subject. As seen in (2a), (2d), (3), as opposed to (4)-(5), the ergative-nominative divide is further correlated with distinct agreement suffixes for the third person singular. Ergative subjects have $-s$, while nominative subjects have $-n .^{3}$ Thus, the choice of the TS is an indicator of the argument structure of the verb and the ergative-nominative

${ }^{3}$ PL has a fairly complex agreement sytem involving both prefixation and suffixation (Demirok 2011; 2013):

\begin{tabular}{|c|c|c|c|c|c|c|}
\hline \multirow[t]{3}{*}{ Prefixes: } & \multicolumn{2}{|c|}{ Subject markers } & \multicolumn{2}{|c|}{$(v$-set) } & Object markers & $(m$-set $)$ \\
\hline & $1 \mathrm{p}$ & & $\mathrm{v}-[\mathrm{p}$ & $, \mathrm{p}, \mathrm{b}]$ & $1 \mathrm{p}$ & $\mathrm{m}-$ \\
\hline & $2 p$ & & $\emptyset$ & & $2 \mathrm{p}$ & g- \\
\hline \multirow[t]{4}{*}{ Suffixes: } & \multicolumn{3}{|l|}{ Present set } & \multicolumn{2}{|c|}{ Past set } & \\
\hline & $1 p \& 2 p$ & $\emptyset$ & & $1 \mathrm{p} \&$ & $\mathrm{p}-\mathrm{i}$ & \\
\hline & $3 p . s g$ & $-\mathrm{n} /-$ & & 3p.sg & $-\mathrm{u}$ & \\
\hline & 3p.pl & -nar & /-an & 3p.pl & -es & \\
\hline
\end{tabular}

Agreement suffixes also encode temporal information, and are, thus, grouped into two as past and present sets. They also systematically denote the structural subject of the sentence (Öztürk 2010). Only nominative and ergative subjects can control the agreement suffixes and thus act as the structural subject, whereas datives cannot.

(i) a. Ali-k i-çaliş-am-s.

Ali-ERG VAL-work-ts-pRS.3SG 'Ali is working.'

(ii) a. Ali nca-şe ey-ul-u-n. Ali tree-ALLAT PV- climb-TS-PRS.3SG 'Ali is climbing the tree.' b. Ma v-i-çaliş-am- $\emptyset$.

I 1SBJ-VAL-work-TS-PRS.1SG 'I am working.'

b. Ma nca-şe eyo-v-ul-ur- $\emptyset$. I tree-ALLAT PV-1SBJ-climb-TS-PRS.1SG 'I am climbing the tree.'

(iii) a. Ali-s muti var a-cer-e-n.

Ali-DAT nothing NEG APPL-believe-TS-PRS.3SG

'Ali believes in nothing.'

b. Ma muti var m-a-cer-e-n.

I nothing NEG 1OBJ-APPL-believe-TS-PRS.3SG

'I believe in nothing.'

Agreement prefixes, on the other hand, are grouped into two as $\boldsymbol{v}$-set and $\boldsymbol{m}$-set (Holisky 1991); while the $v$-set constitutes the subject markers and marks nominative and ergative subjects, the $m$-set can represent either dative arguments (goals/benefactives/experiencers), or nominative objects. 
marking of the subjects signals their macro roles. Initiator/causer always receives ergative case and Undergoer the nominative case. ${ }^{4}$

The TSs are also sensitive to lexical aspectual properties of the verb. While verbs selecting -am or -um denote activities as in (2a) and (3a) and accomplishments as in (2d) and (3b), verbs selecting $-u(r)$ denote achievements as in (4).

Table 1 below shows the classification of non-derived verbs with their associated semantic and morphological features:

Table 1: Classification of non-derived verbs with their associated semantic and morphological features

\begin{tabular}{lllcll}
\hline Macro roles & Arg. type & Case & Val. marker & 3sg.agr. TS Lexical asp. \\
\hline I. Initiator & unergative & ergative & i- $/ \emptyset$ & $-\mathrm{s}$ & -am activity \\
II. Undergoer & unaccusative nominative & $\emptyset$ & $-\mathrm{n}$ & -ur achievements \\
III. Initiator + transitive & ergat., nom. & $\emptyset$ & $-\mathrm{s}$ & -am activity, accomp. \\
Undergoer & transitive & ergat., nom. & $\emptyset$ & $-\mathrm{s}$ & -um activity, accomp. \\
\hline
\end{tabular}

As seen in the table above, intransitive verbs fall into two basic verb classes: unergatives with an ergative marked Initiator as the subject and unaccusatives with a nominative Undergoer as the subject. Transitive verbs which always take an ergative subject and a nominative object differentiate between whether the object's form is affected or not and this differentiation is signaled by the choice of the TSs -am vs. -um. Note that the table above does not include statives and transitive achievements, which will be discussed in section 3.3 due to their special morpho-syntax. As seen in (6), both the transitive achievement and stative verbs share the same root, but are differentiated by their TS and valency markers:

(6) al Ali-k Ayşe o-cer-am-s.

Ali-ERG Ayşe VAL-convince-TS-PRS.3SG

'Ali is convincing Ayşe.'

(transitive achievement)

\footnotetext{
${ }^{4}$ We use van Valin's (Van Valin \& LaPolla 1997; Van Valin 2005) macro roles of Actor and Undergoer to refer to the general semantic roles of NPs sharing the same morpho-syntactic properties. The same concept is captured by the proto-roles of Dowty (1991) (i.e., proto-agent and proto-patient) and super-roles of Croft (1998). We prefer the term Initiator over the term Actor because not all semantic roles (such as experiencer) which have the same morpho-syntactic property in other languages, pattern in the same way in PL. Experiencers in PL, for example, take the dative and require applicative morphology on the verb.
} 
b. Ayşe-s muti var a-cer-e-n.

Ayşe-DAT nothing NEG APPL-believe-TS-PRS.3SG

'Ayşe believes in nothing.' (Lit.: 'Nothing convinces Ayşe.')

(stative)

The fourth TS -e(r) occurs only in derived structures. In combination with the valency marker $i$ - it constructs intransitive verbs with passive/middle/ anti-causative readings necessarily implying external causation. Thus, all transitive verb types have a derived $i-\ldots$ - $(e) r$ form. Examples $(7 \mathrm{a}-\mathrm{b})$ illustrate the intransitive forms of the transitive verbs in (2a) and (3a), respectively:

(7) a. Dişk'a i-t'ax-e-n.

wood VAL-break-TS-PRS.3SG

'The wood is (being) broken.' b. Toyiç'i i-zd-e-n.

rope VAL-pull-TS-PRS.3SG

'The rope is (being) pulled.'

Now we will take a closer look at the semantic and morphosyntactic properties of unergatives, unaccusatives and transitives in PL.

\subsection{Unergatives}

Unergatives in PL which select the TS - am and have an ergative Initiator express unbounded atelic activities and comprise two types of verbs: (a) agentive intransitives, such as walk, work, bark, play, etc., and (b) verbs of emission such as (water) bubble, (flower) smell, (sun) shine, (lightning) light, (thunder) clap, etc. As noted in Rappaport Hovav \& Levin (2000, 28), verbs of emission, which are temporally unbounded (atelic) and non-scalar just like activities, are unergative across languages. Unergatives express an eventuality that is internally caused; the instigator may be an animate agent, as in (8) or an inherent property of the entity as in verbs of emission as in $(9 \mathrm{a}-\mathrm{b})$ and (10). Note that there is a morphological difference on the verb form of the agentive intransitives versus verbs of emission; agentive verbs always have the valency marker $i$-, which will be argued to be a marker of argument suppression (section 3).

(8) Ali-k i-çaliş-am-s.

I VAL-work-TS-PRS.3SG

'I am working/work.'

(9) a. Gurgul-am-s.

clap-TS-PRS.3SG

'Thunder claps/is clapping.' b. Layçhi-k tzumin-am-s.

dog-ERG bark-TS-PRS.3sG

'The dog is barking/barks.' 


\subsection{Unaccusatives}

Unaccusatives with the TS $-u(r)$ require nominative Undergoer subjects and express an eventuality where the undergoer has gone through some change of state. The change is predominantly internally caused but can be externally caused, too. The verbs that fall into this group denote achievements, such as pop, crack, degree achievements, such as (sun) rise/set, rot, scab, darken, get warm, etc., and verbs of directed motion: e.g., enter, descend, climb, exit, etc. ${ }^{5}$

(10) Xava mts'up-u-n.

weather get.dark-TS-PRS.3SG

'It is getting/gets dark.' (Lit.: 'The weather is getting/gets dark.')

(degree achievement)

(11) Bere nca-şe ey-ul-u-n.

child tree-ALLAT PV-climb-TS-PRS.3SG

'The child is climbing/climbs the tree'

(verb of directed motion)

(12) Balon-epe t'vats-u-n.

balloon-PL pop-TS-PRS.3SG

'The balloons are popping/pop.'

(achievement)

Verbs of directed motion with agentive or non-agentive subjects also pattern as unaccusatives in PL, taking a nominative subject and TS $-u(r)$ following the cross-linguistic pattern (Levin \& Rappaport Hovav 1995). In the PL classification of single argument verbs, it is the nature of the change in the eventuality that is the crucial determinant; that is, eventualities which express a non-scalar change (e.g., unergatives) constitute a different set than those which express a scalar change. Rappaport Hovav's $(2008,17)$ typology of scalar changes where all changes of scalar nature are categorized into the following three types captures the classification in $\mathrm{PL}:{ }^{6}$

(i) property scales: change of state verbs, e.g., lengthen, dim, open, close, widen, etc.

${ }^{5}$ It should be pointed out that verbs of directed motion are, in fact, all derived from one and the same verb having the general meaning of 'move' (i.e., ulun) by means of different spatial prefixes which then specify the type of directed motion.

${ }^{6}$ As defined in Rappaport Hovav $(2008,17)$, "A scalar change is one which involves an ordered set of changes in a particular direction of the values of a single attribute and so can be characterized as movement in a particular direction along the scale." 
(ii) path scales: position of a theme along a path (directed motion verbs), e.g., descend, enter, exit, go, etc.

(iii) volume/extent scales: incremental theme verbs, eat, read, build, etc.

Single argument verbs that express some change of state along a scale belong to the unaccusative class and take the TS $-u(r)$. The change can be either in the property of the undergoer as in achievement verbs, or in the position of the entity along a path as in verbs of directed motion. Single argument verbs involving a non-scalar change, such as shout, laugh, walk, etc., on the other hand, belong to the unergative class and take the TS -am. Thus, the scalar vs. non-scalar nature of change in the eventuality underlies the choice of $-a m$ or $-u(r)$. While sunsetting in (13) involves an incremental, scalar change and selects $-u(r)$, sunshining in (14) expresses no scalar change and hence selects -am:

(13) Mjora cul-u-n.

sun set-TS-PRS.3SG

'The sun is setting/sets.'

(14) Mjora-k farfal-am-s.

sun-erg shine-TS-PRS.3SG

'The sun is shining/shines.'

Unergatives are internally caused as opposed to unaccusatives where the undergoer goes through some change due to either internal (10)-(11) or external (12) causation.

\subsection{Transitive verbs in PL}

Transitive verbs have ergative subjects with the macro role of Initiator but they have a choice in their TS between -am vs. -um. This choice rests on the nature of affectedness of the undergoer, such that transitive verbs with unaffected objects (bring, hit, pull, plant, open, close, wash dishes, etc.) select -am, as in (15) while those with affected objects where the object undergoes some change in form (break, knead, fry, chew, build, fold, draw, drink, wash laundary, etc.) select -um, as shown in (16). Although verbs like bring, plant, open, close involve a change, this change is only a change of position, but not that of form/shape/constituition/volume, therefore, they are not grouped under the -um category. 
(15) Ahmedi-k t'abaxi çx-am-s.

Ahmet-ERG plate wash-TS-PRS.3SG

'Ahmet is washing/washes the plate.'

(16) Ayla-k zimari şol-um-s

Ayla-ERG dough knead-TS-PRS.3SG

'Ayla is kneading/kneads the dough.'

As illustrated earlier, all transitive patterns in PL have a corresponding derived $i-\ldots-e(r)$ intransitive form implying external causation. However, some transitive verbs are also compatible with $-u(r)$, as given in $(17 \mathrm{~b})$. This is used when one wants to express the resultant state of a change (i.e., metal is in a bent state) and the natural internal property of the undergoer (i.e., a metal, such as copper, has the intrinsic property of bending). Example (17c) with $i$-...-e(r) verb form, on the other hand, implies that bending of the metal is due to an external factor. Thus, if an object does not have the intrinsic property of being bendable (e.g., steel), it can only have an unaccusative form with $i-\ldots-e(r)$.

(17) a. Ali-k ham metali ndrikh-um-s.

Ali-ERG this metal bend-TS-PRS.3SG

'Ali is bending/bends this metal.'

b. Ham metali ndrukh-u-n.

this metal bend-TS-PRS.3sG

'The metal is bendable/bending/can bend.'

c. Ham metali i-ndrikh-e-n. ${ }^{7}$

this metal VAL-bend-TS-PRS.3SG

'This metal is being bent/bending/bendable (by an external force).'

Note that both (17b) and (17c) have a dynamic modal (ability/capacity) reading in addition to the progressive reading. It is the context which disambiguates between the modal and the progressive interpretations. ${ }^{8}$

${ }^{7}$ The verb root undergoes internal vowel alternation indexed to the choice of -um or $-u(r)$ in this group.

${ }^{8}$ Note that verbs with $-a m$ and $-u m$ in PL lack the modal reading that $-u(r)$ and $-e(r)$ exhibit. This asymmetry is reminiscent of Smith's (1997) classification of imperfectives in Chinese, where -zai marks dynamic progressive and -zhe marks stative imperfective. In PL, too, stative and dynamic imperfectives differ with respect to the TS they take. The TSs $-u(r)$ and $-e(r)$ express stativity, which follows from their use as a derivational suffix forming deverbal nouns (i) and adjectives (ii), respectively: 
There are other transitive verbs that do not have an $-u(r)$ intransitive form. The constraint is that if a verb has a lexicalized agentive manner (e.g., smear) or implication for use of an instrument (e.g. cut), this suggests strong agency and makes these verbs unsuitable for $-u(r)$ intransitives.

\section{Transitive syntax of verbs in PL}

In the following, we will analyze the architecture of the verbal complex and show that all verb types, including unaccusatives and unergatives are mapped onto syntax transitively involving both an initiator and an undergoer. We will first discuss unergatives and unaccusatives which are canonical examples of intransitives in many languages. Then, we will focus on the syntactic composition of stative verbs in PL, which is the most unlikely eventuality type to involve a transitive relation between an initiator and an undergoer. We will show that even statives in PL depict transitivity, as they are always formed with a transitive root which then has its special morphology.

Before moving on to the syntax of different verb types, we would like to address the question of what TSs represent in syntax as morphological markers denoting imperfectivity, argument structure and lexical aspect, simultaneously. Ramchand and Svenonius (2013) show that the progressive, a subtype of imperfective, belongs to the eventive domain along with voice and theta role information, unlike the perfective, which belongs to the situation domain along with tense. The fact that the progressive closely interacts with the lexical aspect of the verb it embeds, unlike the perfective is taken to be one piece of evidence for such a domain split in English. They propose that the progressive aspect heads the projection $v_{\text {Evt }} \mathrm{P}$ right above the VP introducing the initiator and creates a dynamic eventuality description. As shown above, TSs in PL as markers of imperfectivity also select verbs based on their lexical aspectual properties. In the spirit of

\begin{tabular}{|c|c|c|c|}
\hline \multirow[t]{3}{*}{ (i) } & a. dotan-uri & b. opurk-uri & c. lazut'i t'ax-uri \\
\hline & sun.rise-TS & bloom-TS & corn break-TS \\
\hline & 'the rising of the sun' & 'the blooming (of flowers)' & 'reaping corns' \\
\hline \multirow[t]{3}{*}{ (ii) } & a. t'ax-eri cami & mi t'ax-eri on. & \\
\hline & break-Ts glass & ass break-TS PRS.3SG & \\
\hline & 'broken glass' & he glass is broken.' & \\
\hline
\end{tabular}

As noted by Vendler (1967), the dynamic modal reading is an inherent property of statives. Thus, it is only the $-u(r)$ and $-e(r)$ imperfectives which encode such a modal reading in PL. See Taylan (2011) for different types of modalities in PL. 
Ramchand \& Svenonius (2013), we argue that TSs in PL head a projection on top of the vP layer introducing the initiator, which we label as EventP, and depict different eventualities. Thus, they also reflect information regarding both the argument structure and the lexical aspect of the verb as seen in (18).

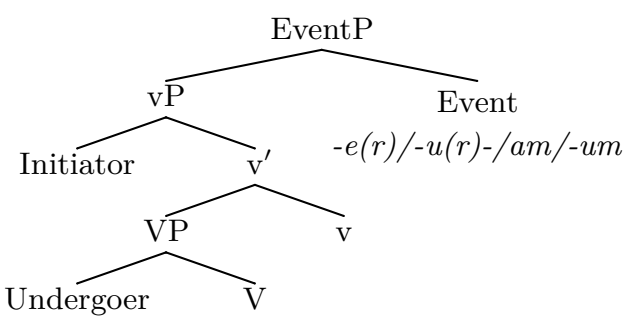

\subsection{Unergatives}

Recall that it was shown in section 2 that unergatives with animate agentive (19a) or non-animate subjects (verbs of emission) (19b) always take the TS -am, which we also find in transitives:

(19) a. Ali-k i-çalış-am-s.

Ali-ERG VAL-work-TS-PRS.3SG

'Ali is working.' b. Ayna-k farfal-am-s.

mirror-ERG shine-TS-PRS.3SG

'The mirror is shining.'

However, agentive unergatives, different from verbs of emission, bear the valency marker $i-{ }^{9}$ We observe the same marker in reflexive constructions in PL as in (20b), which surfaces as a result of argument reduction via reflexivization and stands for the suppressed undergoer:

(20) Ma yali-s Ahmed b-dzir-i.

I mirror-DAT Ahmet 1P-see-PST.1SG

'I saw Ahmet in the mirror.' b. Ma yali-s v-i-dzir-i.

I mirror-DAT 1P-VAL-see-PST.1SG

'I saw myself in the mirror.'

9 There is a set of valency markers in PL, which occur immediately preceding the verbal root and following the agreement prefixes. In addition to the reflexive $i$-, there are also the causative $o^{-}$, the passive/middle marker $i$-, applicatives $a$-, $u$ - and $i$-. Note that there is only one morphological slot available on the verbal complex, which means that only one valency marker can surface and the one which is the highest in terms of c-command hierarchy is chosen (Demirok 2011; 2013). The applicatives $u$ - and $i$ - are associated with different persons, $u$ - denotes 3sg, while $i$ encodes $1 \mathrm{sg}$ and $2 \mathrm{sg}$. The applicative $a-$, on the other hand, is a complex marker, which surfaces when the structure requires both the passive/middle marker $i$ - and one of the person denoting applicatives, $u$ - or $i$-. 
We take the presence of this marker in unergatives to imply that the event is acted upon one's self. Example (19a) can be taken to mean 'Ali is making himself work'. Thus, the ergative initiator simultaneously behaves as the causer, rendering the event as an internally caused one. This then would imply that the marker $i$ - in agentive unergatives stands for an undergoer co-indexed with the initiator as depicted in (21). Hence, they are always transitive.

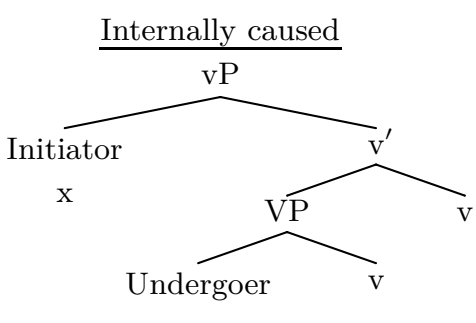

$\mathrm{X}$

In languages like English, unergatives can also be used transitively but only in telic contexts as seen in (22b), where a goal/bounded path is introduced. Note that the undergoer in English does not have to be a reflexive coindexed with the initiator, but it can be an independent DP yielding an externally caused reading:

(22) a. *John walked himself/the old lady.

b. John walked himself/the old lady out/to the park.

There is also cross-Caucasian evidence for the marker $i$-acting as a reflexive undergoer. In Georgian, a close relative of Laz, as shown in (23b), the marker $i$ - surfaces only when the unergative is used in perfective contexts (Cyrino Lazzarini 2012), where the event is terminated or completed. But in PL telicity or termination/completion is not a requirement for $i$ - to surface, as observed in (19a):

(23) a. Bavshv-i tamash-ob-s balax-ze.

child-NOM play-TS-3SG grass-ON.DAT

'The child plays on the grass.'

b. Bavshv-ma i-tamash-a balax-ze.

child-ERG VAL-play-3SG.AOR grass-ON.DAT

'The child played on the grass.'

(Cyrino Lazzarini 2012)

Another transitive pattern which is observed cross-linguistically with unergatives is that they can take cognate objects. For example, in Turkish, 
which PL is in close contact with, some unergatives can easily take cognate objects, regardless of telicity:
(24) a. Çocuk oyun oyn-uyor.
child game play-IMP
b. Bebek uyku uyu-yor.
baby sleep sleep-IMP
'The child is game-playing.'
'The baby is sleep-sleeping.'

If the marker $i$ - in $\mathrm{PL}$ agentive unergatives is saturating the undergoer role of these verbs, then the prediction would be that they cannot take cognate objects. This prediction is borne out as shown in (25).

(25) *Ali-k nciri i-ncir-s.

Ali-ERG sleep VAL-sleep-PRS.3SG

'Ali sleep-sleeps.'

Thus, we claim that agentive unergatives in PL naturally involve a vP layer and can be considered to be syntactically transitive involving an overt ergative marked initiator and a reflexive undergoer.

The other type of unergatives in PL are verbs of emission, which do not require the marker $i$-. It has been observed in the literature that verbs of emission have a causal implication, which leads to the external merge of their sole argument (Potashnik 2012):

(26) a. The flower smells.

b. The flower causes the smell.

The ergative marking of the sole argument of such verbs in PL provides support for this causal implication. However, since verbs of emission in PL lack the marker $i$-, which we claim stands for the undergoer, such verbs may be seen as problematic for the transitivity analysis proposed here. These might constitute the only intransitive pattern in PL. On the other hand, for verbs of emission, it is still possible to assume the conflation model proposed for unergatives by Hale and Keyser (2002) as shown in (27).

(27)

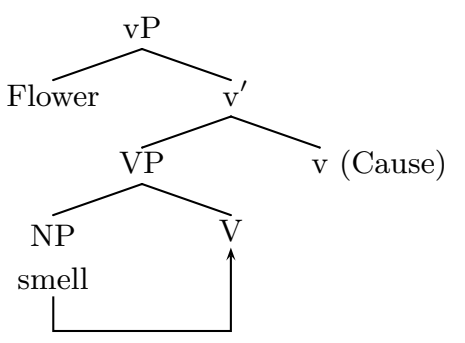


Thus, if we assume the conflation model, verbs of emission would be syntactically derived from a noun which conflates into a light verb, which then makes it is possible to argue that such verbs also stem from a transitive pattern.

It is possible to find nominal counterparts of verbs of emission as in (28a). Note that it is possible to paraphrase (28b) as (28d) with an overt light verb, but not possible to use the nominal form as the object of a verb of emission, as in (28c), showing that unlike languages like Turkish, the object position of verbs of emission is not available for cognate objects. This implies that the conflated object saturates the argument structure of the light verb.

(28) a. Gurgula ce-xt-u.

lightning PV-fall-PST.3SG

'Lightning struck.'

b. Ntsa-k gurgul-am-s.

sky-ERG clap-TS-PRS.3SG

'Thunder is clapping.' (Lit.: 'The sky is lightning.')

c. ${ }^{*}$ Ntsa-k ar didi gurgula gurgul-u.

sky-ERG a big thunder clap-TS-PST.3SG

'The sky clapped a big thunder.'

d. Ntsa-k gurgula ik'-um-s.

sky-ERG thunder make-TS-PRS.3sG

'The sky is making thunder claps.'

\subsection{Unaccusatives}

In the following we aim to show that, just like unergatives, both externally caused unaccusatives formed with $-e(r)$ or $-u(r)$ and the internally caused unaccusatives with $-u(r)$ involve a vP layer introducing an initiator in their syntactic architecture and thus are also transitive.

\subsubsection{Externally caused intransitives derived from transitives with $-e(r)$ and $-u(r)$}

Unlike languages like English where there are different constructions for passives, anti-causatives and middles, the PL imperfective constructions formed with $-e(r)$ depending on the context can yield either a middle reading or an existential passive reading. However, we argue that these constructions, though they can semantically accommodate the anti-causative 
reading, are syntactically different from the anti-causatives found in languages like English, because they always involve a $\mathrm{vP}$ layer introducing the initiator in addition to the undergoer in their syntax.

(29) a. Ara i-t'ax-e-n.

branch VAL-break-TS-PRS.3SG

'The branch is breaking/being broken.'

i. Somebody is breaking the branch.

ii. *The branch is breaking by itself.

b. Ek'na mol-i-zd-e-n.

door PV-VAL-close-TS-PRS.3SG

'The door is closing/being closed.'

i. Somebody/some force is closing the door.

ii. *The door is closing by itself.

As seen in the interpretations of the examples in (29), it is not possible to have an interpretation where the undergoer acts by itself without an initiator. ${ }^{10}$ We argue that this is an indication for the presence of a $\mathrm{vP}$ layer in these constructions. A further piece of evidence that they involve a $\mathrm{vP}$ layer comes from the fact that the imperfectives formed with $-e(r)$ are compatible with purpose clauses, instrumentals and initiator-oriented adverbs as shown in (30). This implies that they should involve a vP-layer to introduce the initiator/causer.

(30) Cami k'asi-te amolva şeni ç'ak'uç'i-te i-t'ax-e-n

glass intention-with enter for hammer-with VAL-break-TS-PRS.3SG

'The glass is intentionally broken with a hammer to enter.'

As seen in (29) and (30), there is also morphological evidence for the presence of an initiator in these constructions. Derived unaccusative verbs formed with $-e(r)$ bear the valency marker $i$-, noted also to be used with agentive unergatives and reflexives. In PL, there are no agentive by-phrases or by itself-phrases as the ones found in languages such as English, which can differentiate between passives and anti-causatives (Alexiadou et al. 2006). We argue that this is because in the constructions formed with $-e(r), i$ - as a marker already saturates the external argument of the predicate. Similar to the $i$ - standing for the undergoer in reflexives, the marker $i$ - in derived unaccusatives semantically saturates the initiator (Chierchia

${ }^{10}$ Note that our informant is a Laz and Turkish bilingual. Even though Turkish morphologically differentiates between passives and anti-causatives, our informant translated the examples with $i$-...-(e)r verb form into Turkish with passive morphology and systematically rejected the anti-causative version. 
1995). When it is bound by an existential operator it yields an existential passive reading, or when a generic operator binds it, it leads to a middle reading. ${ }^{11}$ Thus, we argue that these constructions are syntactically transitive involving both an initiator and an overt nominative undergoer. This then implies that these constructions do not have the same structure as the anti-causatives in English, which lack an initiator introducing the vP layer.

Recall that the derived unaccusatives denote an ability/capacity of the undergoer which can be brought about by an external force. If the external force is to be specified, then it is introduced as a dative DP via applicative morphology, which then would bind the marker $i$-. However, there is a second reading available in these constructions, where the dative DP does not bind $i$-and is simply interpreted as the benefactive argument of a passive construction (31b). ${ }^{12}$

(31) Ali-s cami a-t'ax-e-n.

Ali-DAT glass APPL-break-TS-PRS.3SG

a. 'Ali can break the glass.' b. 'The glass is being broken for Ali.'

11 See Lekakou (2002) for the operators contributed by imperfective morphology in middles.

It was suggested by one of the anonymous reviewers that $i$ - both in externally caused derived unaccusatives and agentive unergatives could be viewed simply as an intransitive marker. There are two types of evidence against this view. First, PL already has a marker which signals that there is only one full DP associated with the verb as an argument, namely, -in as shown in (33). Second, $i$ - does not always appear on all types of single argument verbs, such as verbs of emission and underived unaccusatives. We believe $i$ - in PL is analogous to the impersonal $s i$ in Italian (Chierchia 1995).

Another reviewer suggested that in derived unaccusatives the marker $i$ - could be associated with the undergoer rather than the initiator in parallel to the reflexive $i$ - in agentive unergatives. If this were the case, we would predict it to also occur in transitive constructions, e.g. under the scrambling of the undergoer, as observed in clitic left dislocation constructions as in languages like Italian and Arabic. However, though PL allows for scrambling in transitive constructions with overt initiators and undergoers, $i$ - never surfaces. Therefore, we assume it to be associated with the initiator rather than the undergoer in derived unaccusative constructions.

12 Note that when a third person benefactive is introduced to a transitive construction with an overt ergative subject, the applicative morphology would surface as $u$ - on the verbal complex as in (i). However, in constructions like (31), which underlyingly involve $i$-, the applicative morphology is realized as $a$-. See also footnote 9 .

(i) Ayşe-k Ali-s cami u-t'ax-um-s.

Ayşe-ERG Ali-DAT glass APPL-break-TS-PRS.3SG

'Ayşe is breaking the glass for Ali.' 
As seen in (33a), in such imperfective constructions, to highlight the dynamic modality reading resulting from an external force, it is possible to use the suffix -in right before the TS. This suffix surfaces in $\mathrm{v}$ head when intransitives are causativized in PL, denoting that there is only one argument overtly realized, as in (33b), which fills up the $\mathrm{v}$ head in the structure (32).

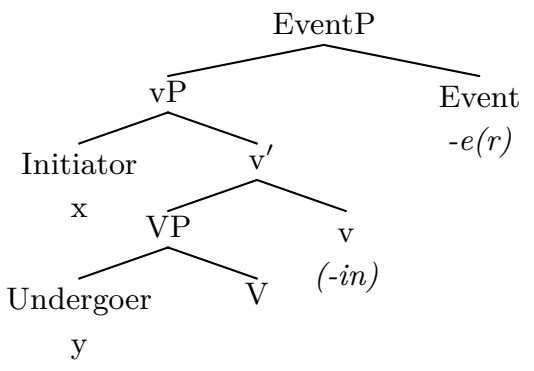

(33) a. Cami i-t'ax-in-e-n.

glass CL-break-CAUS-TS-PRS.3SG

'Glass is breakable/can be broken.'

b. Ali-k Ayşe o-çaliş̧-in-am-s.

Ali-ERg Ayşe VAL-work-CAUS-TS-PRS.3SG

'Ali is making Ayşe work.'

Now we turn to unaccusatives formed with $-u(r)$ as in (34a), which also have transitive counterparts taking -am or -um with an overt external initiator as in (34b). Even in these constructions it is possible to detect the implicit initiator with initiator-oriented adverbs, purpose clauses, instrumentals, even though they do not involve a marker like $i$-, as in (34):

(34) a. Noti k'elemi-te Ali-s parti goşinu şeni nç'ar-u-n.

note pen-with Ali-DAT party remind for write-TS-PRS.3SG

'The note is written (in a written form) with a pen to remind Ali of the party.'

b. Ayşe-k noti nç'ar-um-s.

Ayşe-ERG note write-TS-PRS.3SG

'Ayşe is writing a note.'

Therefore, we argue that $-u(r)$ unaccusatives with transitive counterparts also involve a vP layer in their derivation, which hosts an implicit external argument as shown in (35). 
(35)

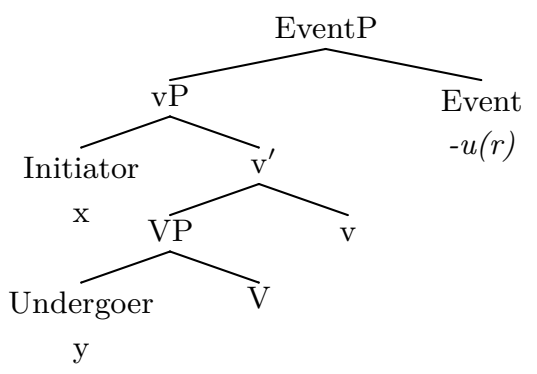

To summarize, we have shown that all externally caused unaccusatives in $\mathrm{PL}$ involve the $\mathrm{vP}$ layer introducing the implicit or explicit initiator in their syntax. Thus, these unaccusatives are transitive syntactically and PL lacks the type of unaccusatives like anti-causatives that languages like English have, which only consists of a VP layer but no vP projection.

$\begin{array}{llcc}\text { The door opens easily } & \text { Middle } & \checkmark & \checkmark \\ \text { The door was opened } & \text { Passive } & \checkmark & \checkmark \\ \text { The door opened. } & \text { Anti-causative } & * & \checkmark\end{array}$

\subsubsection{Internally caused unaccusatives}

Internally caused unaccusatives, as in (37), also make use of the TS $-u(r)$ and include change of state verbs, such as achievements, degree achievements, verbs of directed motion.

(37) Ombri purk-u-n.

plum.tree bloom-TS-PRS.3sG

'The plum tree blooms/is blooming.'

The evidence for the transitivity of internally caused unaccusatives comes from three different sources. First, it is possible for the internally caused unaccusatives to take the TS - um and have an ergative subject, still retaining the intransitive reading but implying that the undergoer has control over the caused change:

(38) Ombri-k purk-um-s.

plum.tree-ERG bloom-TS-PRS.3SG

'The plum tree blooms.' (e.g., in winter due to some internal control)

Second, both (37) and (38) are compatible with purpose clauses, instrumentals and initiator oriented adverbials, regardless of the case of the subject. 
(39) a. Ombri purkinora megalu şeni didi purki-pe-te guri cedv-eri plum.tree spring greet for big flower-PL-with heart put-TS purk-u-n. bloom-TS-PRS.3SG

'The plum tree wholeheartedly blooms with big flowers to greet the spring.'

b. Ombri-k purkinora megalu şeni didi purki-pe-te guri cedv-eri plum.tree-ERG spring greet for big flower-PL-with heart put-TS purk-um-s.

bloom-TS-PRS.3SG

'The plum tree wholeheartly blooms with big flowers to greet the spring.'

Third, there is an experiential perfect construction in PL formed with the TS $-u(r)$, which presents the event as an experience of the initiator. As seen in (40a), the perfect construction requires applicative morphology and the suffix $-a p{ }^{13}$ This suffix being the marker used to derive causative constructions from transitive verbs as seen in (40b) surfaces in the $\mathrm{v}$ head.

(40) a. Ayşe-s cami u-t'ax-ap-u-n.

Ayşe-DAT glass APPL-break-CAUS-TS-PRS.3SG

'Ayşe has broken glass.'

b. Ali-k Ayşe-s cami o-t'ax-ap-am-s.

Ali-ERG Ayşe-DAT glass val-break-CAUS-TS-PRS.3SG

'Ali is making Ayşe break the glass.'

As this construction specifically relates to the initiator, transitives, agentive unergatives and verbs of emission with overt ergative initiators can be used in the experiential perfect as shown in (41a), (41b) and (41c), respectively. In the case of unaccusatives, the experiential perfect is only compatible with internally caused unaccusatives $(41 \mathrm{a}-\mathrm{c})$, but not with externally caused unaccusatives (41d), where the external causer is not explicit. This we take as evidence for the presence of an initiator in internally caused unaccusatives, which may be introduced with ergative case depending on the context as in (38). Note that given the grammatical examples in (41c) and (42b) with inanimate subjects, the ungrammaticality in (39d) is not related to animacy but due to the presence of an external causer.

${ }^{13}$ For the different types of applicative constructions available in PL, see Öztürk (2013). 
(41) a. Ali-s cami u-t'ax-ap-u-n.

Ali-DAT glass APPL-break-CAUS-TS-PRS.3SG

'Ali has broken glass.'

b. Hak dido bere-s u-çaliş-ap-u-n.

here many child-DAT APPL-work-CAUS-TS-PRS.3SG

'Many children have worked here.'

c. Ntsa-s u-gurgul-ap-u-n.

sky-DAT APPL-clap-CAUS-TS-PRS.3SG

'Sky has clapped before.'

(42) a. Ombri-s u-purk-ap-u-n.

plum.tree-DAT APPL-bloom-CAUS-TS-PRS.3SG

'The plum tree has bloomed.'

b. Ham zimari-s var u-mbar-ap-u-n.

this doug-DAT NEG APPL-rise-CAUS-TS-PRS.3SG

'This dough has never risen.'

c. Hak Ali-s m-u-lv-ap-u-n.

here Ali-DAT PV-APPL-come-CAUS-TS-PRS.3SG

'Ali has come here.'

d. ${ }^{*}$ Hak kartali-s m-u-lv-ap-u-n.

here letter-DAT PV-APPL-come-CAUS-TS-PRS.3SG

'Letters have come here.'

This asymmetry observed between internally and externally caused unaccusatives in the perfect construction can be interpreted as that internally caused unaccusatives also have a cognate initiator, which is coindexed with the undergoer. This then would imply that even such verbs project transitively in syntax, involving a layer which introduces the initiator in addition to the undergoer as in (43).

(43) Internally caused unaccusative

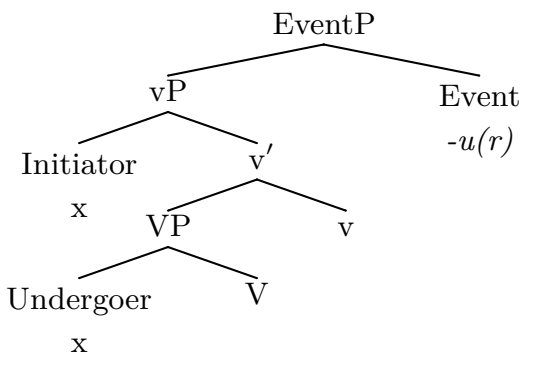

Acta Linguistica Hungarica 61, 2014 


\subsection{Transitive achievements and statives}

Transitive achievements in PL require the valency marker $o^{-}$, in addition to the TS -am:

(44) a. Arte-k daçxuri o-gz-am-s.

Arte-ERG fire VAL-ignite-TS-PRS.3SG

'Artek ignites/is igniting the fire.'

b. Ahmedi-k kva o-t'oç-am-s.

Ahmedi-ERG stone VAL-throw-TS-PRS.3SG

'Ahmet throws/is throwing the stone.'

c. Ali-k Ayşe o-cer-am-s.

Ali-ERG Ayşe VAL-convince-TS-PRS.3SG

'Ali convinces/is convincing Ayşe.'

The same valency marker also surfaces when a causer is added to intransitive and transitive verbs in PL, as illustrated in (33b) and (40b) above repeated below as $(45 \mathrm{a})$ and $(45 \mathrm{~b})$, respectively:

(45) a. Ali-k Ayşe o-çaliş-in-am-s.

Ali-ERg Ayşe VAL-work-CAUS-TS-PRS.3SG

'Ali is making Ayşe work.'

b. Ali-k Ayşe-s cami o-t'ax-ap-am-s.

Ali-ERG Ayşe-DAT glass VAL-break-CAUS-TS-PRS.3SG

'Ali is making Ayşe break the glass.'

The question that needs to be answered is why we find $o$ - in transitive achievements, too. We claim that its presence signals that the event comprises two separate phases. Ergative subjects are only involved in the initiation phase, which leads to some change in the undergoer, but are dissociated from the following second phase, whose semantic subject is the undergoer. For example, in (44b), after Ahmet, i.e., the initiator, throws the ball (initial phase), the stone undergoes an independent movement following a path (second phase). Similarly, causativized events involve more than one phase, with the causer introducing a new phase.

As also mentioned in section 2, some verbal roots, such as cer 'convince' in (44c), which are used to form transitive achievements can also be used to construct derived statives via the applicative marker $a$ - and the TS $-e(r)$ as in (46a). When there is no applicative in the structure, we again find the marker $i$ - in combination with the TS $-e(r)$ as in (46b). Recall that the marker $i$-stands for an implicit initiator. 
(46) a. Ayşe-s muti var a-cer-e-n.

Ayşe-DAT nothing NEG APPL-believe-TS-PRS.3SG

'Ayşe believes in nothing.' (Lit.: 'Nothing convinces Ayşe.')

b. Muti var i-cer-e-n.

nothing NEG VAL-believe-TS-PRS.3SG

'Nothing is believed in/convincing.'

The same alternation in the choice of TSs is observed for the verbs fear vs. scare/frigthen in PL as illustrated in (47). şkur with the TS -(e)r has a stative reading while şkur with the TS -am has a transitive achievement reading.

(47) a. Ali-s layçi'i-şe a-şkur-e-n.

Ali-DAT dog-ABL APPL-fear-TS-PRS.3SG

'Ali fears dogs.'

b. Layçi'i-k Ali o-şkur-am-s.

dog-ERG Ali PV-frighten-TS-PRS.3SG

'The dog frightens Ali.'

As illustrated above, the roots şkur and cer can assume both a dynamic (e.g., scare/frighten and convince) and a stative reading (fear and believe), where the dynamic reading involves a causation and has a transitive structure with an ergative subject and a nominative undergoer.

Furthermore, stative verbs such as have and stand/sit/lie in PL require the TS $-u(r)$, but share the same root as the transitive verbs bring and put, respectively, which take the TS -am. As in (48a) and (49a), the use of $-u(r)$ presents a stative situation resulting from a transitive relation given in (48b) and (49b), respectively (i.e., bring something to someone, or put something somewhere), where the end result of a phase due to some external causation is focused on. Note that the same roots can be constructed with the $i-\ldots-e(r)$ with an externally caused passive unaccusative reading, as in the (48c) and (49c) respectively.

(48) a. Ma para m-i- $\breve{\mathbf{g}}-\mathbf{u}-\mathbf{n}$.

I money 1OBJ-APPL-bring-TS-PRS.3SG

'I have money.' (Lit.: 'Money is brought to me.')

b. Ma dişk'a me-v-i- $\mathbf{g}-a m-\emptyset$.

I wood PV-1SBJ-bring-TS-PRS.1SG

'I am bringing wood.' 


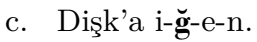

wood VAL-bring-TS-PRS.3SG

'The wood is being brought.'

(49) a. K'alati sva-muşi-s k'asite do-dg-u-n.

basket place-POSS.3SG-DAT intentionally PV-stand-TS-PRS.3SG

'The basket is put in its place intentionally.'

b. Ali-k k'alati sva-muşi-s do-dg-am-s.

Ali-ERG basket place-POSS.3SG-DAT PV-put-TS-PRS.3SG

'Ali is putting the basket in its place.'

c. K'alati sva-muşi-s d-i-dg-e-n.

basket place-POSS.3SG-DAT PV-VAL-put-TS-PRS.3SG

'The basket is being put in its place.'

These examples show us that PL does not have separate lexical items for stative verbs, but makes use of the same roots to construct both statives and transitives by choosing different TSs. The use of the initiator oriented adverb in (49a) implies that similar to (49b-c), this stative construction also involves an implicit initiator syntactically. This shows that statives formed with both $-e(r)$ and $-u(r)$ possess a transitive syntax in PL. ${ }^{14}$

\section{Concluding remarks}

We have argued that all eventualities are mapped onto syntax transitively in PL, as having an initiator/causer which acts upon an undergoer. Following Ramchand (2008) who decomposes eventualities into initiation, process and resultant states, the lexical span of all verbs in PL always include initiation and process both syntactically and semantically, and also the resultant state, depending on the type of verb. Through the use of different TSs, different stages of transitive eventualities, such as initiation, process and resultant state, are foregrounded. Thus, in PL we can either have verbs involving only the initiation and the process, excluding a resultant state, such as hit, kick, walk, sing, wash, or verbs involving all three stages, such

${ }^{14}$ We do not claim that we have exhausted all types of statives in PL. However, the statives in PL seem to behave mostly as Davidsonian states, rather than Kimian states (Maienborn 2008). Since PL presents eventualities always transitively involving the initiator, one prediction would be that there cannot be verbs denoting Kimian states in this language. However, this requires a thorough investigation of statives in PL. 
as break $k_{\text {transitive }}$, fry, bend, cool, warm, etc. What is missing in PL are verbs involving only the process and the resultant state excluding the initiation, e.g., break $k_{\text {intransitive }}$. The lexical span of two verb types in PL and how TSs foreground different stages of the eventualities they denote are shown in the schema below:

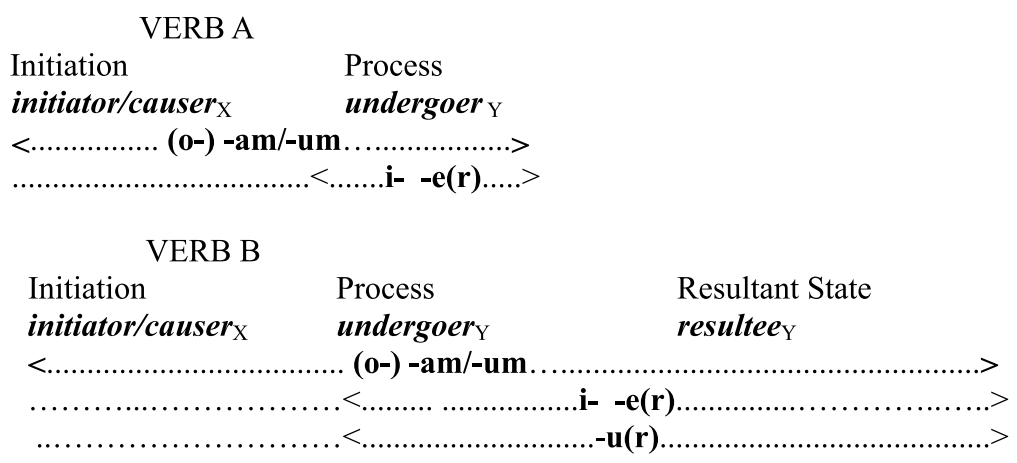

In one sense, PL compares to Chol, where what you call a verb always requires a complement, hence an undergoer, so that only transitives and unaccusatives are categorized as verbs, but not unergatives, which surface as nominal constructions (Coon \& Preminger 2013). Verbs in PL not only require an undergoer but also an initiator, assuming a common transitive syntax for transitives, unaccusatives and unergatives. ${ }^{15}$

\section{References}

Alexiadou, Artemis, Elena Anagnostopoulou and Florian Schäfer. 2006. The properties of anticausatives crosslinguistically. In M. Frascarelli (ed.) Phases of interpretation. Berlin \& New York: Mouton de Gruyter. 187-21.

Anderson, Ralph D. 1963. A grammar of Laz. Doctoral dissertation. University of Texas at Austin.

Chierchia, Gennaro. 1995. The variability of impersonal subjects. In E. Bach, E. Jelinek, A. Kratzer and B. H. Partee (eds.) Quantification in natural languages. Dordrecht: Kluwer. 107-143.

Coon, Jessica and Omer Preminger. 2013. Transitivity in Chol: A new argument for the Split VP Hypothesis. In L. Fainleib, N. LaCara, and Y. Park (eds.) Proceedings of NELS 41. Amherst, MA: GLSA. 1-14.

15 Note that with this property PL constitutes a canonical example of an Inititiationlanguage typologically. For a discussion of Initiation versus Delimitiation languages, see Ritter \& Rosen (2000). 
Croft, William. 1998. Event structure in argument linking. In M. Butt and W. Geuder (eds.) The projection of arguments lexical and compositional factors. Stanford, CA: CSLI Publications. 1-43.

Cyrino Lazzarini, Joao Paulo. 2012. A semantic map approach to the Georgian preradical vowel $i$-. Paper presented at Caucasus: Typology and Theory Conference at Boğaziçi University, Istanbul.

Demirok, Ömer. 2011. Verbal complex. In B. Öztürk and M. Pöchtrager (eds.) LINCOM: Languages of the world materials. Münich: LINCOM. 44-68.

Demirok, Ömer. 2013. Agree as a unidirectional operation: Evidence from Pazar Laz. MA thesis. Boğaziçi University.

Dowty, David R. 1991. Thematic proto-roles and argument selection. Language 67. 547-619.

Hale, Kenneth and Samuel Jay Keyser. 2002. Prolegomenon to a theory of argument structure. Cambridge, MA: MIT Press.

Holisky, Dee Ann. 1991. Laz. In A. C. Harris (ed.) Indigenous languages of the Caucasus. Delmar, NY: Caravan Books. 395-472.

Hopper, Paul and Sandra A. Thompson. 1980. Transitivity in grammar and discourse. Language 56. 251-299.

Kutscher, Silvia, Johanna Mattissen and Anke Wodarg. 1995. Das Mut'afi-Lazische. Köln: Universität zu Köln.

Lacroix, Rene. 2009. Description du dialecte laze d'Arhavi. Doctoral dissertation. University of Lumiere Lyon 2.

Lekakou, Marika. 2002. Middle semantics and its realization in English and Greek. UCL Working Papers in Linguistics 14. 399-416.

Levin, Beth. 1999. Objecthood: An event structure perspective. In Proceedings of CLS 35. Volume 1: The Main Session. Chicago: University of Chicago. 223-247.

Levin, Beth and Malka Rappaport Hovav. 1995. Unaccusativity. At the syntax-lexical semantics interface. Cambridge, MA: MIT Press.

Maienborn, Claudia. 2008. On Davidsonian and Kimian states. In I. Comorovski and K. von Heusinger (eds.) Existence: Semantics and syntax. Dordrecht: Kluwer. 107130 .

Öztürk, Balkız. 2010. Subjects in Pazar and Ardesheni Laz. Dilbilim Araştırmaları 2010/1. 33-50.

Öztürk, Balkız. 2013. Low, high and higher applicatives: Evidence from Pazar Laz. In V. Camacho-Taboada, Á. L. Jiménez-Fernández, J. Martín-González and M. ReyesTejedor (eds.) Information structure and agreement. Amsterdam \& Philadelphia: John Benjamins. 275-296.

Öztürk, Balkız and Markus Pöchtrager. 2011. Pazar Laz. Münich: LINCOM.

Potashnik, Joseph. 2012. Emission verbs. In M. Everaert, M. Marelj and T. Siloni (eds.) The theta system: Argument structure at the interface. Oxford: Oxford University Press. 251-278.

Ramchand, Gillian. 2008. Verb meaning and the lexicon: A first phase syntax. Cambridge: Cambridge University Press.

Ramchand, Gillian and Peter Svenonius. 2013. Deriving the functional hierarchy. Paper presented at GLOW 36, Lund. 
Rappaport Hovav, Malka. 2008. Lexicalized meaning and the internal temporal structure of events. In S. Rothstein (ed.) Theoretical and crosslinguistic approaches to the semantics of aspect. Amsterdam \& Philadelphia: John Benjamins. 13-43.

Rappaport Hovav, Malka and Beth Levin. 2000. Classifying single argument verbs. In P. Coopmans, M. Everaert and J. Grimshaw (eds.) Lexical specification and insertion. Amsterdam \& Philadelphia: John Benjamins. 269-304.

Ritter, Elizabeth and Sara Rosen. 2000. Event structure and ergativity. In C. L. Tenny and J. Pustejovsky (eds.) Events as grammatical objects: The converging perspectives of lexical semantics and syntax. Stanford: CSLI Publications. 187-238.

Taylan, Eser. 2011. Mood and modality. In Öztürk \& Pöchtrager (2011, 74-85).

Van Valin, Robert D. Jr. 2005. Exploring the syntax-semantics interface. Cambridge: Cambridge University Press.

Van Valin, Robert D. Jr. and Randy J. LaPolla. 1997. Syntax: Structure, meaning and function. Cambridge: Cambridge University Press.

Vendler, Zeno. 1967. Linguistics in philosophy. Ithaca, NY: Cornell University Press. 